\title{
George W. Bush’s Domestic Policy Agenda
}

\author{
Matthew Eshbaugh-Soha and Tom Miles
}

\begin{abstract}
The president's domestic policy agenda is the starting point for the yearly give-and-take beween presidents and Congress. It also reflects the president's efforts to achieve good public policy, reelection, and historical achievement. This paper extends research that has explored the president's domestic policy agenda to the George W. Bush Administration by cataloging the size, length, and importance of Bush's yearly domestic policy agenda priorities. Supplemented with three case studies on education, social security, and charitable choice policies, this paper demonstrates the necessity of moving fast and having public support to explaining the content and ultimate success of George W. Bush's yearly legislative domestic policy agendas.
\end{abstract}

Agenda-setting is at the crux of power and influence in American politics (Cobb and Elder 1983; Kingdon 1995; Schattscneider 1960). Influencing "the set of issues that receives serious attention from policymakers" (Edwards and Wood 1999, 327) or the definition of policy alternatives before policymakers is one of the most important sources of power in American politics and is a necessary first step in the policymaking process (Anderson 2000). Generally, scholarship concurs that presidents are positioned to be primary agenda-setters in our governmental system (Baumgartner and Jones 1993; Kingdon 1995), even though much research illustrates numerous limitations to presidential agenda-setting (Edwards and Wood 1999; Eshbaugh-Soha and Peake 2005).

Regardless of the extent to which presidents influence the consideration of policy alternatives, research confers much importance to the president's own legislative policy agenda, which provides a typical beginning to the yearly policy process and is vital to a successful legislative presidency. Bond and Fleisher $(1990,230)$ write that "the president's greatest influence over policy comes from the agenda he pursues and the way it is packaged." Light (1999, 156-57) illustrates how Congress expects presidents to provide it with top policy priorities to maximize limited resources (e.g., presidential approval, support in Congress), which are needed to be successful.

Thanks to Ryan Salzman for assisting with data collection, and to the University of North Texas for providing research assistance.

MATTHEW ESHBAUGH-SOHA is an assistant professor of political science at the University of North Texas. TOM MILES is a doctoral candidate in the Department of Political Science at the University of North Texas.

The American Review of Politics, Vol. 29, Winter, 2008-2009: 351-369

(C)2008 The American Review of Politics 
Eshbaugh-Soha (2005) infers that presidential success may be endogenous to the president's domestic policy agenda in part because presidents consider factors that are vital to success in Congress when they first propose legislation. Other research notes that presidents can set the legislative agenda (Edwards and Barrett 2000) and that policies on the president's agenda are more likely to succeed in Congress than those not on his agenda (Covington, Wrighton, and Kinney 1995; Peterson 1990).

Several factors help explain the president's agenda. First, the broader political environment will affect agenda size, content, and success. Presidents are more likely to be successful on legislation when their party controls Congress and their job approval ratings are high (Edwards 1989). As such, presidents will offer more numerous and major policy initiatives when these circumstances are favorable to the president (Eshbaugh-Soha 2005). Second, the regularities of presidential time affect the president's agenda such that presidents are more likely to be successful when they "hit the ground running" and are more likely to offer a larger domestic policy agenda with more major policy initiatives during their first-year honeymoon (Light 1999). Yet, presidents may be more effective in dealing with Congress as they learn about what works and what doesn't.

This paper will apply the general consensus in the literature to the domestic policy agenda of the George W. Bush Administration. Again, dependent in part on the broader contextual environment as well as two cycles of presidential time, the president's domestic policy agenda should vary substantially. These same factors may also influence whether President Bush's domestic policy agenda was successful. The questions answered in this paper are: what types of domestic policies did President George W. Bush pursue? And was his agenda strategy an effective one? To answer these questions, we collect data on President Bush's eight yearly domestic policy agendas and divide into four policy types. We supplement our discussion with case studies on three of Bush's top domestic policy prioritieseducation, social security, and faith-based initiatives - to elaborate upon factors that contributed to President Bush's top successes and most significant policy failures.

\section{The President's Agenda}

The president's agenda is a typical beginning in the yearly give-andtake between presidents and Congress. Defined by Light (1999, 2-3) as a "signal, [which] indicates what the President believes to be the most important issues facing his administration," presidents present their legislative priorities to Congress in part because Congress needs this leadership (Neustadt 1990) to overcome collective action problems (Moe 2002) that promote 
legislative inactivity. Although the agenda may evolve over the course of a year as problems arise and solutions are reached, the president's yearly State of the Union Address is the first place to look for the president's top priorities (Light 1999).

The president's agenda is also the starting point for presidents to attempt to achieve three broad goals: good public policy, reelection, and historical significance (Light 1999; Pfiffner 1988). Presidents desire good public policy, not only to accomplish what they promised they would achieve during their initial election campaign, but also to have a policy record on which to run and be reelected. A successful policy agenda, therefore, helps presidents achieve their second goal of reelection. The significance and permanence of the policies on the president's agenda, naturally, also contribute to a presidency's historical relevance. Each of these three accomplishments, to come full-circle, begins with a well-reasoned, considered, and strategized domestic policy agenda.

As a way to characterize a large and diverse set of yearly policy initiatives and ascertain the extent to which the president's agenda contributes to or limits achievement of his broad goals, scholars have used various categorizations to reduce this information into a more manageable set of priorities. Both Light (1999) and Peterson (1990) characterize presidential agenda items in terms of their size and novelty. Eshbaugh-Soha (2005) builds upon Light's research and explores time and importance dimensions of presidential priorities in a typology similar to Light (1999) and Peterson (1990). Focusing upon the size of the agenda, alone, Ragsdale (1993, 376-77) has offered three agenda styles with which to characterize the president's agenda and its likelihood (conditional upon other factors, of course) for success. "Grand simplification" focuses on a few policies; "modest strides" encourages a few more policies (more of a middle ground); and "encyclopedic design" comprises presidential agendas that offer a lot of everything.

Each of these classification schemes suggests that the larger political environment provides opportunities — or presents constraints—for presidents and their policy agendas. Although a president is free to offer any number of large, major, or otherwise significant policy proposals in any given year, the president is likely to offer a more expansive agenda given a favorable political environment. What is more, the likelihood of success is contingent upon the available resources and opportunities. That is, presidents have more opportunities to succeed when conditions favor their success in the first place (i.e., when their party controls Congress and they are popular). Public support for the president's own policy priorities also increases the degree to which presidents publicize those policies in the first place which contributes to a higher likelihood of success (Canes-Wrone 2001). Knowing this, presidents should propose more major policies under favorable circumstances. 
Less favorable conditions may encourage fewer major policy initiatives but, perhaps, additional minor or less significant policy initiatives. Surely, agenda size matters, too, as Ragsdale (1993) contends. The larger the agenda, the more favorable the congressional context must be for it to be successful, such as with Lyndon Johnson's sizeable Democratic majorities in Congress, high job approval ratings, and a landslide victory in the 1964 presidential election. Presidents who face conditions of divided government and low job approval ratings are less likely to be as ambitious (EshbaughSoha 2005), and offer smaller and less expansive domestic agendas.

Indeed, focusing on a handful of domestic policy priorities typically benefits the president most, except when conditions are overwhelmingly favorable for pursuing an "encyclopedic" agenda. Presidents who are perceived to have been unsuccessful or unskilled in dealing with Congress are those who typically tried to do too much too soon. Jimmy Carter is one example (Hargrove 1988) of a president who failed to set clear priorities for Congress early in his first year. His program, instead, was "too extensive and too disorganized" (Light 1999, 158). Clinton is another president who misjudged his majority in Congress, was sidetracked by low priorities (e.g., gays in the military), and proposed a major health care bill in September, well after any honeymoon period. Lacking clear priorities contributes to poor communication, a waste of the president's limited time and energy, and too many items for limited legislative agenda space, which also compete with legislators' own priorities (Light 1999, 231). Even if presidents have a relatively high percentage of success later in their terms, these early decisions are particularly important to a president's reputation as a skillful legislative president.

Along with variable political conditions, presidential time may also affect the propensity of presidents to offer sizeable and major domestic policy agendas and be successful pushing these proposals through Congress. Indeed, Light (1999) has identified two cycles of presidential influence. The cycle of decreasing influence suggests that presidents are most likely to succeed in Congress with their first-year policy agenda. It is during a president's first-year honeymoon, after all, that an electoral mandate-if present-is most likely to affect legislators' support for the president (Peterson, Grossback, Stimson, and Gangl 2003) and when presidents typically have the public's support. As time proceeds, capital is spent, and failures mount, presidential influence in Congress should decrease. Yet, even as the president's influence wanes, effectiveness in managing the White House and dealing with Congress waxes. This cycle of increasing effectiveness means that presidents become more skilled in dealing with Congress as they make mistakes and learn from them. Taken together, Light (1999) suggests that the best time to succeed on fundamental policy reform is when these cycles 
intersect, usually during a shorter, but potentially more fruitful second-term honeymoon.

\section{Data Collection}

We collect data on President George W. Bush's domestic policy agenda using a two-step process to identify the president's domestic policy priorities per calendar year, borrowed from Eshbaugh-Soha (2005). First, as Light $(1999,5)$ notes, that "the President's top priorities will always appear in the [State of the Union] message at some point during the term." ${ }^{\text {Y }}$ Yet, the State of the Union Address (SUA) is also a laundry list of policies suggested by not only the president, but also by federal agencies and departments. Looking at the State of the Union Address alone is, therefore, insufficient for determining the president's top policy priorities. Because of this, our second step is to identify the list of policy proposals from the SUA in another speech by the president. In short, a policy priority has to be mentioned in the SUA first, and then repeated in at least one speech during the calendar year. Of course, this is not an exhaustive list of items on the larger policy agenda, just a sample of presidential policy priorities. Indeed, as Larocca $(2006,65)$ points out, it is quite difficult to fully capture the agenda with any single operationalization. Because presidents may prioritize items that are initially proposed by Congress, we do not differentiate between presidential or congressional initiatives; only whether or not the president made the policy a priority as conceived by our coding scheme.

Once we identify a set of presidential priorities, we next determine the nature of these policy initiatives and place them into a two-by-two policy typology, characterized by their time-whether short- or long-term-and importance. A policy priority is considered to be long-term if it is to be enacted or funded for four years or more, including those policies that are permanent (subject to judicial review or legislative amendment, of course). When the president requests substantial funding (typically over \$10B per year) or otherwise addresses an obvious and "principal problem” (Light 1999) facing society, we coded it as an important policy. Crossing time and importance dimensions of public policy produces four policy areas: major, minor, incremental, and meteoric. We focus on major and minor policy areas in our analysis, and provide examples of each policy type in Table 1.

\section{A First Look at the Bush Agenda}

President George W. Bush governed during a mix of political circumstances. By moving fast on a handful of domestic policy items and maintaining at least an initially positive relationship with Congress (Johnson 
Table 1. Sample Policies from George W. Bush's Domestic Agenda

\begin{tabular}{|c|c|}
\hline Long-term & Short-term \\
\hline $\begin{array}{l}\text { Major } \\
\text { No Child Left Behind } \\
\text { Social Security Reform }\end{array}$ & $\begin{array}{l}\text { Meteoric } \\
\text { Emergency Spending (2002) } \\
\text { Tax Stimulus (2008) }\end{array}$ \\
\hline $\begin{array}{l}\text { Incremental } \\
\text { Project Bioshield (2003) } \\
\text { Modernize Electric Power Grid } \\
\text { (2004) }\end{array}$ & $\begin{array}{l}\text { Minor } \\
\text { Healthy Forests (2003) } \\
\text { American Competitiveness } \\
\text { Initiative (2006) }\end{array}$ \\
\hline
\end{tabular}

2004), the Bush Administration succeeded in cutting taxes and reforming education policy. Bush's domestic agenda, as the data will show, reached its zenith early in his tenure in part because Republicans briefly lost control of the Senate and the administration faced the greatest national security problem of the modern era: international terrorist attacks on American soil. Nevertheless, Bush's approval ratings soared, Republicans gained seats in both houses of Congress during the 2002 midterm elections, and the public initially supported an invasion of Iraq. But as circumstances changed yet again, as the administration failed to deal with Hurricane Katrina effectively and the Iraq war dragged on, the president's approval ratings plummeted and Republicans lost control of Congress in the 2006 midterm elections. Although the president's domestic policy agenda did not benefit from his surge in popularity following September 11, 2001, deteriorating political circumstances surely doomed any remaining policies on his domestic agenda after his 2007 State of the Union address.

Much of the early evidence surrounding the Bush domestic policy agenda suggests that these later political developments had little direct impact on the crux of his domestic policy strategy, which involved moving fast and was very much like Ragsdale's (1993) "grand simplification" scheme (see Johnson 2004, 173). As such, it was also akin to Ronald Reagan's: put resources behind a handful of key issues to ensure their success in Congress (see Light 1999). Indeed, Sinclair $(2008,168)$ offers that President Bush's domestic policy strategy was comprised of four main goals: focus on a 
handful of ambitious legislative initiatives, be firm in negotiations over policies, go public, and begin with the House of Representatives, which, as a majoritarian institution controlled by Republicans, offered the best prospects for presidential success on the substance of legislation (see Barrett and Eshbaugh-Soha 2007). Yet, President Bush engaged in both partisan (for tax cuts) and bipartisan (education policy) strategies to enact his domestic policy agenda, despite a rather mixed record of success overall. In addition, the evidence suggests the President Bush's domestic policy agenda was comprised of a modest number of major policy initiatives, balanced by a similar number of minor policy proposals. Whether or not this is representative of Bush's entire domestic policy agenda remains to be seen.

\section{Findings}

During his two terms in office, President George W. Bush put forth a rather ambitious but concise domestic policy agenda. He pushed tax cuts (see Edwards 2002), education reform, and a charitable choice or faith-based program (see Black, Koopman, and Ryden 2004) as his top priorities during his first year in office. Bush proposed other initiatives during his first-year address to Congress, including funding a prescription drug benefit through Medicare, energy reform, and social security reform. Bush repeated many of these proposals in subsequent State of the Union Addresses, succeeding on prescription drugs in 2003 and an energy policy in 2005. Yet, Bush failed to reform social security despite making it his top second-term domestic policy priority. Bush's entire domestic policy agenda was rather balanced, with a blend of major and minor policy proposals that varied over his terms, and which met with mixed legislative success.

Table 2 reveals that President Bush pushed an array of legislative initiatives. The size of his agenda ranged from 14 requests in 2001, his first year in office, to a low of 3 new proposals in his last State of the Union Address. Then, it is not surprising to find that Bush offered the largest number of new major policies in 2001 (nine), including education reform and tax cuts, and the fewest in 2008 (zero). The number of minor policies remains fairly constant over Bush's tenure, ranging from 1 in 2003 to 6 new minor initiatives in 2004. His minor policy proposals included passage of the Healthy Forests Initiative, a short-term effort to thin National Forests to reduce forest-fire risk, and repeated efforts to fund conversion of health care records to electronic format, at the cost of $\$ 100$ million.

The numbers in Table 2 disclose the unique position of a second-term president who did not achieve much of what he wanted during his first term. Most of Bush's requests in 2005 were holdovers from his first term in office. In other words, among the 44 new first-term proposals, 15 of these carried 
Table 2. George W. Bush's Yearly Domestic Policy Agenda

\begin{tabular}{lccccc}
\hline Year & Total New-Repeats & Major & Minor & Incremental & Meteoric \\
\hline 2001 & $14-0$ & 9 & 2 & 3 & 0 \\
2002 & $10-5$ & 3 & 4 & 2 & 1 \\
2003 & $8-7$ & 5 & 1 & 2 & 0 \\
2004 & $12-5$ & 2 & 6 & 4 & 0 \\
Term1 & $44-17$ & 19 & 13 & 11 & 1 \\
2005 & $7-15$ & 1 & 3 & 1 & 2 \\
2006 & $4-7$ & 1 & 2 & 1 & 0 \\
2007 & $7-10$ & 1 & 5 & 1 & 0 \\
2008 & $3-12$ & 0 & 2 & 0 & 1 \\
Term2 & $21-44$ & 3 & 12 & 3 & 3 \\
Total & $\mathbf{6 5 - 6 1}$ & $\mathbf{2 2}$ & $\mathbf{2 5}$ & $\mathbf{1 4}$ & $\mathbf{4}$ \\
\hline
\end{tabular}

over and were continuing priorities of the president during his second term in office. Among these 15 priorities, seven were major initiatives (e.g., social security, making tax cuts permanent) and four were minor policy proposals (e.g., federal money to computerize medical records). President Bush was not willing to offer many substantively new policies in his second term, with numerous first-term proposals remaining unfulfilled.

Nevertheless, the data support the notion that presidential time will cause fluctuations in the president's domestic policy agenda. President Bush offered his largest and most major agenda of new policy initiatives during his first year in office, perhaps hoping to take advantage of a positive honeymoon period, however brief given a seemingly absent electoral mandate (Edwards 2007, chapter 4). Another notion of presidential time, that the best time to propose significant reform is when the cycles of decreasing influence and increasing effectiveness intersect at the beginning of the president's second term, may not only have encouraged President Bush to pursue social security reform in 2005, but also led to Bush's largest yearly domestic policy agenda, even though most of these proposals were repeated holdovers from his first term in office. One should not underestimate, either, that the president's relationship with Congress was unlikely to remain as "cheerful" as it had been during the 107th and 108th Congresses (Johnson 2004, 167).

The data in Table 3 offer a comparison with the other two most recent two-term presidents, Reagan and Clinton, and reveal some similarities with each. At least in terms of size and patterns of yearly, total proposals, President George W. Bush's domestic policy agenda matches well with the 
Table 3. The Policy Priorities of Presidents Reagan, Clinton, and Bush

\begin{tabular}{|c|c|c|c|c|c|c|}
\hline President & Year & Total & Major & Minor & Incremental & Meteoric \\
\hline \multirow[t]{4}{*}{ Reagan1 } & 1981 & 11 & 1 & 7 & 2 & 1 \\
\hline & 1982 & 12 & 4 & 5 & 3 & 0 \\
\hline & 1983 & 13 & 5 & 5 & 2 & 1 \\
\hline & 1984 & 8 & 2 & 3 & 0 & 3 \\
\hline \multirow[t]{4}{*}{ Reagan2 } & 1985 & 3 & 1 & 1 & 1 & 0 \\
\hline & 1986 & 1 & 1 & 0 & 0 & 0 \\
\hline & 1987 & 6 & 1 & 1 & 4 & 0 \\
\hline & 1988 & 3 & 0 & 0 & 3 & 0 \\
\hline \multirow{4}{*}{ Clinton1 } & 1993 & 24 & 8 & 3 & 7 & 6 \\
\hline & 1994 & 7 & 2 & 0 & 4 & 1 \\
\hline & 1995 & 13 & 4 & 3 & 5 & 1 \\
\hline & 1996 & 3 & 1 & 0 & 2 & 0 \\
\hline \multirow[t]{4}{*}{ Clinton2 } & 1997 & 9 & 3 & 0 & 3 & 3 \\
\hline & 1998 & 3 & 1 & 2 & 0 & 0 \\
\hline & 1999 & 10 & 6 & 1 & 3 & 0 \\
\hline & 2000 & 8 & 2 & 4 & 1 & 1 \\
\hline \multirow[t]{4}{*}{ Bush1 } & 2001 & 14 & 9 & 2 & 3 & 0 \\
\hline & 2002 & 10 & 3 & 4 & 2 & 1 \\
\hline & 2003 & 8 & 5 & 1 & 2 & 0 \\
\hline & 2004 & 12 & 2 & 6 & 4 & 0 \\
\hline \multirow[t]{4}{*}{ Bush2 } & 2005 & 7 & 1 & 3 & 1 & 2 \\
\hline & 2006 & 4 & 1 & 2 & 1 & 0 \\
\hline & 2007 & 7 & 1 & 5 & 1 & 0 \\
\hline & 2008 & 3 & 0 & 2 & 0 & 1 \\
\hline
\end{tabular}

Source: Taken from Eshbaugh-Soha (2005) and updated by the authors.

anecdotal comparisons of his policy agenda with President Ronald Reagankeep in mind that aside from his tax cuts, many of Reagan's first year proposals were short-term spending cuts. Each had major tax cut proposals that passed Congress and each prioritized a major reform in his second term in office: Reagan successfully reformed the tax code, while Bush chose to push social security reform.

Bush's domestic policy agenda met with only modest success. If we exclude those policies that were later repeated by the president and reconsidered by Congress after the 2004 presidential election-examining only those policies that did not carry over to the president's second term-Bush was successful on over half of his priorities, 16/29 or 55.2 percent. Taking numerous holdovers as priorities of Bush's second term, in addition to any new proposals, Bush was quite unsuccessful, at 31 percent (11/35) during his 
second term in office. Overall then, Bush's legislative success rate was a modest 44.6 percent (29/65). Without question, being reelected gave Bush additional time and perhaps capital needed to secure adoption of priorities that did not pass during his first four years in office. If Kerry had defeated Bush in the 2004 presidential election, Bush would not have had the opportunity to pursue failed first-term policies in his second term, which would have led to a legislative success rate of 36.4 percent, with only 16 of 44 proposals passing either the 107th or 108th Congress. To put this in an even broader context, the two most recent two-term presidents-Reagan and Clinton — had comparable success rates of 52 and 66 percent, respectively.

President Bush's domestic policy success varied significantly by his years in office. Bush's most successful year, naturally, was his first, with 7 of 14 first-year priorities (50 percent) passing Congress. Bush's least successful year was 2004 , with all but one new priority-a $\$ 12.8 \mathrm{~B}^{2}$ request for Pell Grant funding - failing. Most of these carried over to Bush's second term, but the only significant proposals among these that eventually passed were part of the Energy Policy Act of 2005.

Thinking about policy content, Bush's success rate on major policies was 40.9 percent (9/22) overall, 58.3 percent (7/12) in the first term, with 5 of these being first-year priorities. Bush was also more successful on minor policies (4/9, 44.4 percent) during his first than second term (6/16, 37.5 percent). These data reveal that Bush's strategy of "hitting the ground running" with his major policy priorities worked. Nevertheless, he was unable to sustain this level of success in later years of his first term, despite continued Republican control of Congress and high approval ratings. ${ }^{3}$ It is up to future research to determine whether this was a product of the time and energy that the White House and Congress devoted to foreign policy in a post-911 world and not due to other changes in the political environment.

Table 4. George W. Bush's Legislative Success

\begin{tabular}{cccc}
\hline & Term1 & Term2 & Total \\
\hline Major & $7 / 12$ & $2 / 10$ & $9 / 22$ \\
& $(58.3)$ & $(20)$ & $(40.9)$ \\
Minor & $4 / 9$ & $6 / 16$ & $10 / 25$ \\
& $(44.4)$ & $(37.5)$ & $(40)$ \\
Total & $16 / 29$ & $12 / 36$ & $29 / 65$ \\
& $(55.2)$ & $(33.3)$ & $(44.6)$
\end{tabular}

Note: Percentages are in parentheses. 


\section{Three Case Studies in Bush Policy}

To examine further George W. Bush's domestic policy agenda, we have selected three policies to explore what worked, what did not, and, perhaps, answer why. Because each was the president's top priority for his first and second terms, we will explore education policy, including passage of Bush's No Child Left Behind initiative, and Bush's unsuccessful efforts to reform Social Security. Third, we examine Charitable Choice, a top priority of Bush's first term, and one that neither passed nor failed Congress, but which Bush had to adopt unilaterally with Executive Order 13279, issued on December 12, 2002. Presented in the context of specific conditions President Bush faced while pursuing key components of his yearly domestic policy agendas, these case studies provide some additional support for circumstances that contribute to domestic policy success and those that influence its failure.

\section{Education}

Education reform was Bush's self-proclaimed top priority of his first year in office. In many ways, this was not a surprise. Governor Bush had championed education standards, including the Texas Assessment of Academic Skills (TAAS) ${ }^{4}$ standardized test designed to measure Texas public school and student performance. Failure to meet basic standards would lead, potentially, to state takeover of a school (Haney 2000); and, it also tied teachers' and administrators' jobs to student performance. What is more, the public ranked education as the most important problem during the 2000 presidential election and supported a single set of national standards to fix what the American people saw as a failing public school system (McGuinn 2006, 149; see Mucciaroni and Quirk 2004). Not only did Bush have the ideas to propose as soon as he took office-including those that had failed to pass the 106 th Congress ${ }^{5}$ and many ideas that had been proposed by previous administrations (Rudalevige 2003) — he also had public support to justify his efforts. Conditions in Congress were ripe for education policy reform in 2001, too. The Elementary and Secondary Education Act (ESEA) was not reauthorized for the first time in its history during the 106th Congress (Rudalevige 2003, 33), and many legislators felt compelled to reauthorize and reform federal education policy within the limited window of opportunity that a pro-education reform president had at the beginning of his first term in office.

The goal of President Bush's No Child Left Behind policy was greater responsibility and accountability of public school performance-measured primarily by standardized tests - to ensure that all students received an 
adequate education. Bush's policy included, among other provisions, annual tests, school choice, reading programs, rewards and punishments based on performance, and ways to assess teacher quality (McGuinn 2006, 168). The Bush White House pursued a bipartisan education policy and proposed not a bill, but an outline (Rudalevige 2003). Strategically, this gave Bush the flexibility to reach a bipartisan agreement, regardless of the bill's specifics (McGuinn 2006, 165-172). It helped Bush fulfill not only his campaign promises to reform education, but also do so in a way that would support his claim that he was a "compassionate conservative" and a "uniter, not a divider." The bipartisan coalition was adequate for the narrow passage of many provisions and an overwhelming bipartisan margin in both houses of Congress on final passage. Nevertheless, the bipartisan compromise contributed to the failure of several liberal ideas, including funds for school construction (Mucciaroni and Quirk 2004, 174). Without clear legal support for them (only later reflected in the Supreme Court's support for vouchers in Zelman v. Simmons-Harris (536 US 639 [2002]) the bipartisan coalition also disregarded a key conservative provision: school vouchers (Sinclair 2008, 173).

This case study clearly supports the tenet that "hitting the ground running" is a necessary condition for the passage of major policy initiatives. Yet, despite its initial success in Congress, the implementation and assessment of No Child Left Behind has not been entirely successful (Peterson and West 2003). Indeed, it has received a number of consistent criticisms about lack of funding, standards that are too restrictive, and programs that do not significantly improve school or, ultimately, student performance (see Foreman 2008, 281). As such, even though moving fast may be necessary to clear the adoption stage of the policy process, it is not sufficient for that policy to be implemented or even evaluated successfully. Thus, it could be that the cycle of decreasing influence may undermine the president's success in Congress but could give him time to understand how to carefully and correctly formulate good and enduring public policy during the cycle of increasing effectiveness. Some even suggest that having a "blue print" instead of a detailed bill contributed to the passage of No Child Left Behind (Rudalevige 2003, 36), although this was not true for all of Bush's priorities, including social security reform.

\section{Social Security Reform}

Social security reform provides an opportunity to examine the prospects raised under education policy, that the intersection of the cycles of decreasing influence and increasing effectiveness provide a brief window at the beginning of a second term to help presidents reform significant policy 
areas. President Bush initially mentioned social security reform in the context of high budget surpluses, in his lone pre-9/11 State of the Union Address. It did not become Bush's top domestic policy priority (education and tax cuts held this torch during his first term in office) until after the president's reelection campaign and at the intersection of the cycles of increasing influence and decreasing effectiveness. In his 2005 State of the Union address, Bush devoted 12 paragraphs to it, making up 23 percent of the speech (out of 53 total paragraphs) or 12/26 of the paragraphs devoted to domestic policy, alone; $46 \%$. To emphasize his commitment to reform, Bush then embarked on one of the most significant public relations campaigns in presidential history to push a single policy initiative, a sixty-stop, sixty-day campaign by the president, vice-president, and other key administration officials to sell social security reform to the public and key members of Congress along the way.

Of course, Bush's strategy had not been to develop ideas on social security reform throughout his first term, awaiting the beginning of his second term to propose a well-reasoned and debated policy to reform social security. His reform proposal wasn't even as detailed as his "blue print" for education policy. Instead, it illustrated the perils of not reforming social security and only established broad guidelines for allowing workers to invest part of their payroll contributions that would otherwise go to the social security trust fund in personal investment accounts. Nevertheless, he "pledged to work with members of Congress to find the most effective combination of reforms," ${ }^{6}$ putting much of the burden on legislators to devise policy solutions (Edwards 2007, 220).

This strategy allowed Bush to set the policy agenda, focusing congressional and media attention on reforming social security, but he did not narrow either's gaze on a specific plan of action. Instead, he was determined to use the "bully pulpit" to build congressional and public support for the general idea of reform (Edwards 2007), as evidenced by his claim on the heels of his reelection victory that he had "earned capital in the (2004) campaign, political capital, and now I intend to use it", along with his massive effort to "go local" to communicate the necessity for social security reform to the American people (Eshbaugh-Soha and Peake 2006). Alas, without a clear mandate from the American people, he did not have public support to pursue such lasting reform, as he had with education policy. ${ }^{7}$ What is more, with no policy in hand to address the solvency of social security, putting pressure on Senators to support reform-without knowing the specifics of that reform-did not prove successful.

Indeed, although some conditions for major policy reform were present - the intersection of cycles of presidential time, party control, and a reelection victory—many argue that Bush overreached, that he did not have 
political capital to spend on social security reform or, in Bush's own words, "the third rail of American politics" (McDermott 2005; see Weiner (2007) for a more extensive evaluation of this claim). That entitlement reform in general is difficult surely compounded Bush's difficulties. Perhaps more damning was the means of selling reform and building support. Unlike education policy, Bush's strategy of "going local" to sell personal investment accounts to the public and put pressure on legislators-in a classic, "going public" strategy-raised the stakes for the president and legislators. And, much as Kernell $(1997,34)$ predicted, it made bargaining over policy specifics behind closed doors virtually impossible. Yes, Bush influenced media attention to social security, but this increased public awareness of social security reform actually heightened opposition to reform (Edwards 2007, 258).

\section{Faith-Based Initiative}

Federal charitable choice policy began as a little-noticed provision of the 1996 Welfare Reform Act, which allowed faith-based organizations to apply directly for federal funds as long as those funds were not used for worship, proselytizing, or religious conversion activities. In the 2000 presidential election campaign, candidate Bush made it clear that he would prioritize a more expansive faith-based initiative, with provision similar to the Texas faith-based initiative, pursued by Governor Bush in 1996. Bush campaigned aggressively on an agenda of expanded funding of faith-based agencies that would transfer some of the responsibility for public welfare away from government bureaucracies to local community outreach programs.

Only nine days after taking office in 2001, the new president pressed his Republican allies in Congress to pass laws strengthening charitable choice. His plan faced immediate opposition from both the left, which raised concerns that expanded funding to religious groups directly violated the separation of church and state, and the right, which opposed the initiative on the grounds that it invited and even necessitated government infringement on religious organizations. Despite this opposition, congressional leaders in the House and Senate pressed forward to pass a strong faith-based initiative. Backed by Representative J.C. Watts (R-OK), the Community Solutions Act (H.R. 7, 2001) included important Bush priorities, such as tax exemptions and incentives meant to invigorate donations to charitable organizations that provided aid to the poor and welfare-to-work programs. Although it passed the House, the bill failed in the Senate in part due to questions about "a hiring exemption with regard to homosexuals," which many feared would lead to rampant discrimination (Formicola, Segers, and Weber 2003, 10). 
What is more, Senator Joseph Lieberman (D-CT), a staunch supporter of charitable choice, refused to move the bill forward until the Senate and the White House could resolve jointly important legal issues.

Although the issue would ultimately be pushed off of the legislative agenda by the events of September 11, 2001, resulting in passage of a budget expenditure of only \$30 million dollars in "compassionate capital funds" with no new tax incentives (Black, Koopman, and Ryden 2004, 4), a vital component of Bush's proposal, Bush continued to push a legislative solution to fund faith-based organizations in 2002. The new bill, known as the Charity, Aid and Recovery Empowerment Act (CARE), excluded funds with a clear religious message and mission and any discrimination in hiring practices in an effort to overcome its previous opposition. Without this provision, the bill amounted to little more than a bundle of tax incentives for donations to charitable organizations. It, too, died in the Senate in late 2002.

Frustrated with Congress, on December 12, 2002, President Bush issued two executive orders to help implement Bush's charitable choice provisions and expanded the funding of faith-based organizations. The new Bush plan prohibited federal agencies from discriminating against religious charities and established faith-based offices in six cabinet departments tasked with administering $\$ 7.7$ billion in annual grants to social service providers. In addition, these faith-based offices would provide liaisons to assist religious providers in writing grant proposals to obtain federal funding. With this move, the "Bush administration was faced with the unusual opportunity of being free to implement a virtually dormant current law that they supported and upon which the president had campaigned” (Black, Koopman, and Ryden 2004, 9).

Despite criticism that his executive orders were aimed at garnering political clout with the religious right (Kuo 2006), Bush stayed committed to his faith-based initiative throughout his administration. He featured it in his State-of-the-Union Addresses and called upon Congress to make the provisions of charitable choice permanently codified in law. Like education policy, President Bush brought with him his faith-based ideas from Texas, contributing to a fast-moving effort to adopt charitable choice legislation. Yet, without clear support from Congress or the public, ${ }^{8}$ Bush's decision to prioritize this did not prove successful. Nevertheless, charitable choice represents a unique episode in Bush's role as agenda-setter in which he used executive prerogative to sidestep congressional opposition to a major policy proposal. This may be a lesson for future presidents, that unilateral action is a feasible alternative to enact domestic policy initiatives that fail to generate sufficient support in Congress. 


\section{Conclusion}

What is the legacy of the George W. Bush Administration regarding domestic policy agendas? The Bush presidency provides additional evidence that variation in the broader political environment contributes to similar variation in domestic policy agendas and their success. Bush offered more new and major policies during his first term in office, when he was also most successful. Although Bush's total domestic policy agenda was largest during his first year of his second term, the cycle of increasing effectiveness did not correspond with a greater success rate. Instead, Bush's top three domestic policy priorities reveal not only the importance of moving fast, but also the relevance of clear public support for the president's policy position. Education policy was successful, in part, given public support for reform and Bush's prioritization of the policy early in his term using a bipartisan strategy. Social security reform arguably failed because the public did not support the president's policy solution, nor did he "hit the ground running" with a well-grounded and clear policy designed to generate legislative support. ${ }^{9}$ Although Bush clearly moved fast, arriving in Washington armed with his own Texas faith-based initiative, public support was mixed on this priority and the president was ultimately unable to generate the level of congressional support needed for it to clear numerous legislative hurdles. The longterm utility of faith-based initiatives have further been called into question by the Supreme Court, which has left open the possibility for a state to prevent faith-based organizations from receiving state or federal funding even if these organizations finance only their non-religious services with public funds (Locke v. Davey 540 US 712 [2004]).

The broad results presented in this paper confirm the importance of moving fast with a rather ambitious, but concise, domestic policy agenda. Public support, perhaps not for the president's job, but his position on his policy priorities, appears vital to presidential success on top domestic policy agenda items, too. Given the difficulties presidents face moving public opinion, it makes sense for presidents-who can prioritize any number of policy problems - to focus on issues that the public already supports, early. Although political capital can undoubtedly be replenished by events and other favorable developments, it is imperative that presidents move quickly to mitigate the effects of the cycle of decreasing influence. This paper, therefore, supports previous research and continues to build on our body of knowledge about what influences the president's yearly domestic policy agenda and its success. Whatever George W. Bush's legacy to politics, policy, and the presidency may be, the confirmation of these generalizations is certainly one of his legacies to political science. 


\section{NOTES}

${ }^{1}$ Typically, the president's first address to a joint session of Congress is not called a State of the Union Address, but rather, a statement on Administration goals or something similar. These are included in our references to the State of the Union Address.

${ }^{2}$ The actual appropriation was \$12.4B (Swindell 2004).

${ }^{3}$ Without question, Bush's success rate presented here would have been lower had it not been for the passage of key energy provisions in 2005.

${ }^{4}$ In 1999, the Texas Assessment of Knowledge and Skills (TAKS) replaced TAAS.

${ }^{5}$ Democratic senators Evan Bayh and Joe Lieberman supported a “Three R's Plan” during the 106th Congress that included many of Bush's proposals.

${ }^{6}$ http://www.whitehouse.gov/infocus/social-security/200501/socialsecurity.pdf.

${ }^{7}$ According several Gallup/CNN/USA Today polls, only 41 percent of Americans approved of Bush's handling of social security at the beginning of January, 2005. That number dropped precipitously during Bush's social security reform tour, bottoming out at 29 percent, according to a July 22-24, 2005 poll. Only 44 percent supported personal savings accounts at the end of June, 2005 (Edwards 2007, 257).

${ }^{8}$ An April 10, 2001, Pew Forum on Religion \& Public Life and the Pew Research Center for the People \& the Press revealed that even though 75 percent favored government funding for faith-based organizations, this support varied by religion with less than 40 percent supporting such funds for Muslim mosques or Buddhist temples. What is more, 68 percent worried that faith-based initiatives might lead to excessive governmental involvement with religious organizations.

${ }^{9}$ Although we do not explore this condition, the budget deficit may have also played a role in the failure of social security reform. If surpluses were high in 2005, there may have been greater support among the public and Congress to support a transition to private savings accounts, given more available resources to fund it. Charitable choice reveals similar patterns.

\section{REFERENCES}

Anderson, James E. 2000. Public Policymaking: An Introduction, 4th ed. New York: Houghton Mifflin Company.

Barrett, Andrew, and Matthew Eshbaugh-Soha. 2007. Presidential Success on the Substance of Legislation. Political Research Quarterly 60:100-112.

Baumgartner, Frank, and Bryan D. Jones. 1993. Agendas and Instability in American Politics. Chicago: University of Chicago Press.

Black, Amy E., Douglas L. Koopman, and David K. Ryden. 2004. Of Little Faith: The Politics of George W. Bush's Faith-Based Initiatives. Washington, DC: Georgetown University Press.

Bond, Jon R., and Richard Fleisher. 1990. The President in the Legislative Arena. Chicago: The University of Chicago Press.

Canes-Wrone, Brandice. 2001. The President's Legislative Influence from Public Appeals. American Journal of Political Science 45:313-329.

Cobb, Roger W., and Charles D. Elder. 1983. Participation in American Politics: the Dynamics of Agenda-Building. Baltimore, MD: Johns Hopkins University Press. 
Covington, Cary R., J. Mark Wrighton, and Rhonda Kinney. 1995. A 'PresidencyAugmented' Model of Presidential Success on House Roll Call Votes. American Journal of Political Science 39:1001-1024.

Edwards, George C., III. 2007. Governing by Campaigning: The Politics of the Bush Presidency. New York: Longman.

Edwards, George C., III. 2002. Strategic Choices and the Early Bush Legislative Agenda. PS: Political Science \& Politics 35(March):41-45.

Edwards, George C., III, and Andrew Barrett. 2000. Presidential Agenda Setting in Congress. In Polarized Politics, eds. Jon R. Bond and Richard Fleisher. Washington DC: CQ Press.

Edwards, George C., III, and B. Dan Wood. 1999. Who Influences Whom? The President, Congress, and the Media. American Political Science Review 93:327-344.

Eshbaugh-Soha, Matthew. 2005. The Politics of Presidential Agendas. Political Research Quarterly 58(June):257-268.

Eshbaugh-Soha, Matthew, and Jeffrey S. Peake. 2006. 'Going Local' to Reform Social Security. Presidential Studies Quarterly 36(December):689-704.

Foreman, Christopher H., Jr. 2008. The Breaking of the President: Shifting Context and the Bush Domestic Agenda. In The George W. Bush Legacy, eds. Colin Campbell, Bert A. Rockman, and Andrew Rudalevige. Washington, DC: CQ Press.

Formicola, Jo Renee, Mary Segers, and Paul Weber. 2003. Faith-Based Initiatives and the Bush Administration. Lanham, MD: Rowman \& Littlefield.

Haney, Walt. 2000. The Myth of the Texas Education Miracle. Education Policy Analysis Archives 8(41).

Hargrove, Erwin C. 1988. Jimmy as President: Leadership and the Politics of the Public Good. Baton Rouge: Louisiana State University Press.

Johnson, Bertram. 2004. A Stake in the Sand: George W. Bush and Congress. In High Risk and Big Ambition: The Presidency of George W. Bush, ed. Steven E. Schier. University of Pittsburgh Press.

Kernell, Samuel. 1997. Going Public: New Strategies of Presidential Leadership, 3rd ed. Washington DC: CQ Press.

King, Gary. 1993. The Methodology of Presidential Research. In Researching the Presidency: Vital Questions, New Approaches, eds. George C. Edwards, John H. Kessel, and Bert A. Rockmans. University of Pittsburgh Press.

Kingdon, John W. 1995. Agendas, Alternatives, and Public Policies. Boston: Little, Brown.

Kuo, David. 2006. Tempting Faith: An Inside Story of Political Seduction. New York: Free Press.

Larocca, Roger T. 2006. The Presidential Agenda: Sources of Executive Influence in Congress. Ohio State University Press.

Light, Paul C. 1999. The President's Agenda: Domestic Policy Choice from Kennedy to Clinton. Baltimore, MD: The Johns Hopkins University Press.

McDermott, Joe. 2005. Bush Grabs ‘Third Rail’ in Montco. Morning Call, February 11, p. A1.

McGuinn, Patrick J. 2006. No Child Left Behind and the Transformation of Federal Education Policy, 1965-2005. Lawrence: University Press of Kansas.

Moe, Terry M. 2002. The Presidency and the Bureaucracy: The Presidential Advantage. In The Presidency and the Political System, 7th ed., ed. Michael Nelson. Washington, DC: CQ Press. 
Mucciaroni, Gary, and Paul J. Quirk. 2004. Deliberations of a 'Compassionate Conservative’: George W. Bush’s Domestic Presidency. In The George W. Bush Presidency: Appraisals and Prospects, eds. Colin Campbell and Bert A. Rockman. Washington, DC: CQ Press.

Neustadt, Richard. 1990. Presidential Power and the Modern Presidents. New York: The Free Press.

Olasky, Marvin. 2002. The White House Faith-Based Initiative: What's Going Right, What's Going Wrong? Notre Dame Journal of Law, Politics, and Public Policy 16:355-366.

Peterson, David A.M., Lawrence J. Grossback, James A. Stimson, and Amy Gangl. 2003. Congressional Response to Mandate Elections. American Journal of Political Science 47(July):411-426.

Peterson, Mark A. 1990. Legislating Together: The White House and Capitol Hill from Eisenhower to Reagan. Cambridge, MA: Harvard University Press.

Peterson, Paul E., and Martin R. West, eds. 2003. The Politics and Practice of School Accountability. Washington, DC: Brookings Institution Press.

Pfiffner, James A. 1988. The Strategic Presidency: Hitting the Ground Running. Chicago: Dorsey Press.

Public Papers of the Presidents, 1981-2008, 28 vols. Washington, DC: Government Printing Office.

Ragsdale, Lyn. 1993. Presidential Politics. Houghton Mifflin Company.

Rudalevige, Andrew. 2003. No Child Left Behind: Forging a Congressional Compromise. In No Child Left Behind? The Politics and Practice of School Accountability, eds. Paul E. Peterson and Martin R. West. Washington, DC: Brookings Institution Press.

Schattschneider, E.E. 1960. The Semisovereign People: A Realist's View of Democracy in America. Hinsdale, IL: Dryden Press.

Sinclair, Barbara. 2008. Living (and Dying?) by the Sword. In The George W. Bush Legacy, eds. Colin Campbell, Bert A. Rockman, and Andrew Rudalevige. Washington, DC: CQ Press.

Swindell, Bill. 2004. Labor-HHS Appropriations: No Apple for Education. CQ Weekly (November 27):2796-2799.

Weiner, Terry. 2007. Touching the Third Rail: Explaining the Failures of Bush's Social Security Initiative. Politics and Policy 35:872-897. 